\title{
The Role of Public Relations as A Management Function in Higher Education
}

\author{
Putri Anggreni \\ (University of Mahendradatta) \\ E-mail: gekcay@gmail.com
}

\begin{abstract}
Nowadays, public relations in higher education institution become an integral part of the management team. It must contribute to achieve organizational goals and demonstrate an organizational accountability identified by measurable result. Placement public relations at certain positions in management has consequences in the process of implementation of the public relations function. It happened because the management, workflow and hierarchy greatly affects work patterns as well as patterns of decision making in carrying out communication tasks performed by public relations. The goal of research to find out the role and position in public relations in management education institution (university) in achieving its objectives. After identification of roles and positions performance public relations firm, the study aims to evaluate the performance of public relations as part of management.This study used a qualitative descriptive research method with the study subjects were Mahendradatta University Public Relations and internal stakeholders. Data drawn from interviews with the help of the interview guide and then processed into information that can answer the research objectives. The result of the research shows that not all public relations officers in Mahendradatta University, do their role as real public relations officers. They also do not have the same understanding about the role of a public relations officer will just place public relations in same position as marketing.
\end{abstract}

Key words: public relation, private university, role, reputation.

\section{INTRODUCTION}

The communication function conducted by universities has no difference which with other institutions both government and private institutions. That distinguishing the communication function undertaken by these institutions is public communication component. The public then expanded his understanding Become stakeholders who are individuals and groups within or outside the college institution that has a role in determining Success of the company. College is interesting to be examined from the side of communication conducted by Public Relations because there are specific challenges.

According to Cutlip (1985) colleges face four problems in communication are: (1) Inadequate funding support for institutional roles public in the wider community; (2) Competition to get qualified students needs passion and expensive; (3) Constraints and regulations make the college administration difficult and costs; (4) Academic and ownership freedom is a challenge for internal stakeholders or external.

The issue of accountability is a matter that must be maintained by the university. One indicator of accountability is good communication. Other than that Universities have a significant role in educational development Community. Not just as an educational provider but a college is expected to contribute academically and practically in development. Accountability becomes a more crucial issue in state universities because of the cost the education used for 
raising one of them is obtained from taxes paid by the people. Form of social responsibility of state universities become heavier than related to finance is also related to that output resulting from graduates.

By making Public Relations (PR) the main channel of communication is a big challenge as it relates to media perceptions of relationship work society. Parents of students and prospective students are also the ones who it is important to manage the communication for the benefit of the college. Another interesting aspect is the independence of public relations as a tool management, status and position determine the performance of Public Relations as a tool communication. Position of Public Relations in a company can be a tool identification of work objectives and may also reflect a communication policy outlined by management.

\section{FORMULATION OF PROBLEMS}

The Role of Public Relations in an institution of higher education (university and polytechnics) is very important how management positions relationships society as a management tool greatly determines the output generated by Public Relations. Work program is a sign of Public Relations and management to perform the task. Position and role of Public Relations as well can be identified with the implementation of the work program, what is Public Relations have a work program integrated with management policies or just to be a tool complement the company's overall work program. To what extent flexibility or work autonomy related to structure and work can also be affect the performance of Public Relations as a means of communication between companies and public.

The formulation of the problem in this research are: (1) What is the role and position of Public Relations in management?; (2) How is the performance of Public Relations related to roles and positions provided by university management?

\section{OBJECTIVES OF RESEARCH}

To know the role and position of Public Relations in management at educational institutions in this case universities in achieving goals. After identifying the role and position of Public Relations in the company, with this research aiming to evaluate the performance of Public Relations as part of management.

\section{RESEARCH METHOD}

\section{Type of Research}

Descriptive with qualitative approach. The basic concept of qualitative research defined by Bogdan and Taylor (1975) is as a research procedure resulted descriptive data in the form of written or oral words of people and behavior which can be observed. This approach is directed to the background and the individual as a whole.

Further qualitative research is a particular tradition in the social sciences that are fundamentally dependent on observation in humans within their own territory and in contact with such persons in its language and in its terminology. (Moleong, 2002). Qualitative research at the organizational level in this case can complement research with information to estimate and design a strategy deals with organizations that are difficult to break through. Interpretation methods can be used to generalize the findings in depth to some complexity the course of an organization.

\section{Research Subject}

This research will be conducted at Mehendradatta University with research subjects are: 
Public Relations Officer of Mahendradatta University (Unmar) along with 2 internal stakeholder informants.

\section{Data Source}

The main sources in qualitative research are the words and actions, this is the case is the result of observations or interviews by conducting activities to see, hear and ask questions while the types of data support in other qualitative research is as follows: (a) Written source: Related to this research then the written sources are become a source of data, among others, are corporate documents and agencies related can also be a source of data that can add input from research this; (b) Statistics: In qualitative research can also use statistical data which has been available as an additional source of data for research purposes.

But in qualitative research is not too much basing themselves on the data statistics, but make use of statistical data it is just as a way deliver and direct to the events and events found and sought for themselves in accordance with research objectives (Moleong, 2004).

\section{Data Collection Technique}

The data needed in the researcher is collected by doing interview indepth interview. In digging information using the method interviews, Interviews conducted with unstructured but focused on depth (indepth interview). It aims to find information that is not raw (rigid) or single and more free information, questions and statements can be flowing like a casual conversation. Strengthening informants through the process Interview. Because all communications have consequences, the field of research interviews with forms and content that are not "neutral". The interviewer is a powerful tool which researchers can see about humanity and create opportunities for develops and changes in the person being interviewed. It must be fixed anyway is maintained so that research activities are an opportunity to reveal anything which goes beyond the story into something useful.

\section{ROLE AND PERFORMANCE OF UNIVERSITY}

In this section will be described an analysis of the role and position by the PR University of Mahendradatta. In addition, at the end will be presented the results of performance assessment of PR based on the assessment of stakeholders.

\section{The Role of University}

Before understanding the role of Public Relations in carrying out management functions it is necessary to begin by identifying the PR working model. There are four the Public Relations model formulated by Grunig and Hunt in his Managing Public Relations 1984: press agentry/publicity, public information, two way asymentric and two-way symentric. In detail the models can be described as follows: (a) Press agentry/publicity: intended for the benefit of propaganda, one-way communication, so the message is often incomplete; (b) Public information: The main purpose is dissemination or dissemination of information. One-way communication, not necessarily in a persuasive way; (c) Two-way asymentric: This model is intended for scientific persuasion. Communication two-way, with unbalanced effects; (d) Twoway symentric: This model aims to gain mutual understanding (mutual Understanding), while the communication is two-way with the effects balanced (Gozali, 2010).

Public Relations of Mahendradatta University is working with media/journalists to report objectively to the stakeholders. Two-way communication with stakeholders can not be identified in this research. If analyzed from the results of interviews about the tasks that PR do tend to doing media relations activities. Media relations activity is one of the activities PR is important, but in creating two-way communication required for more direct communication 
(communications) where the PR is active facilitate management to conduct communication process between management and stakeholders. By directional communication is dynamic, in which information is exchanged in two direction between university management and stakeholders. In that communication two-way is the most important thing is the occurrence of feedback. Feedback is information which is important and useful to be input management in carrying out its duties to achieve organizational/university goals.

After discussing about the communication model conducted by Public Relation of Mahendradatta University then discuss about the role. The dominant role of Public Relations in management is identified to be four levels: (a) Expert prescriber, PR officer is considered as an expert who can give advice to the boss. This kind of role is needed at the institution which many have threats and many/often experience change; (b) Problem solving facilitator, acting as a facilitator in the process of solving problems, PR is involved in any management, being a team member or become a leader in crisis management. This kind of role is required on institutions that have many threats but little change; (c) Communication facilitator, acting as facilitator of communication between institutions with the public or as a communication bridge and as a medium or mediator in case of miscommunication. This kind of role is required for the company has few threats but many/often changes; (d) Communication technician, acting as technical communications implementer including providing technical services. This kind of role is required for the company has few threats and changes slightly (Cutlip, 2005).

\section{Position In The Management}

When viewed the structure of the organization PR in the management of the University, they are not in a dominant position. Structurally Public Relations university Mahendradatta is a technical implementation unit. Technical implementation unit in organizational and system of documents work is a necessary supporting element for the organization of education within the University. Public Relations of Mahendradatta University is directly responsible to the rector and coaching is done by Vice Rector II. If seen from the documents of organization and working procedure of Vice Rector II is the only petition Rector in the field of Public Relations in addition to carrying out activities in the field of general administration, planning and finance. The process of bridging management with the public. The Public Relations position has influence in the process of establishing relationships between management and the public. Such that delivered, a public relations practitioner who successfully practices public relations effectively those who use the new model of symmetry as two-way practice. Model Placing the organization with its public on two opposite poles.

Effective public relations practice according to this model is the result of accumulation of the practice of two-way asymetrical and two-way symmetrical models. Each party will persuade to get agreement. In this condition, it could happen that is pure asymetrical model, ie the situation of dominant coalition trying to press the public to accept the position of the organization, or it could happen coorporation model, that is where the situation public use communications to convince dominant coalition to accept positions public.

Furthermore, if the purpose of public relations is incorporated into an organizational goal, public relations executives sit as a dominant coalition. Target public program relations will be more adaptable if the public relations executive is a coalition dominant in the organization. Conversely, if the public relations executive does not sit in a coalition which is dominant, it will be difficult to determine the function of public relations, no matter how the public executive relations tries to fulfill its communication objectives. (Ananto, 2004).

\section{Performance Of Person}


In this research performance of Public Relations seen from stakeholder perception. understanding above contribution of PR in management between internal stakeholders Mahendradatta University. The first informant at the University of Mahendradatta gave an answer to the authority of the publicist that is documentation and publication for activities that scale university and other university leaders informant gave additional that the PR is structurally directly under the rector. Informants at the University of Mahendradatta give an opinion that preach and then if there are outsiders who need information about Mahendradatta University that is public he can issue.

Other informants argue that the responsibility and authority of PR is imaging campus. So how to imaged this campus well so that it can be known all over community layer. Opinions given by each informant have not been able provide an appropriate and detailed perception of responsibility and authority of PR in the university. That function PR is a multi-perception. Confusion about the role and function of PR is still very high, even to the level of decision makers. In Khasali (2010), Management PR, stated that there are several viewpoints in viewing Public Relations. Viewing PR in the viewpoint: (a) Personality; (b) In terms of communication; (c) Publications; (d) Marketing; (e) Management; (f) Advertising.

The view of the perception of public relation is an advantage. Being a excellence when made a However tasks and functions of Public Relations as in the document organization and working procedures is not something which is suitable for university characteristics that have challenges in solving problems as disclosed by Cutlip (1985), universities face four problems in communication that is: (a) Insufficient funding support to run the role of a public institution in the wider community; (b) Competition to get a qualified student needs to be passionate and expensive; (c) Constraints and regulations make the college administration difficult and requires cost; (d) Academic and ownership freedom is a challenge for internal stakeholders or external.

Especially for Public Relations Mahendaratta University, stakeholders stated that still need to be improved coordination between Public Relations with other parts. Head of Public Relations Mahendradatta University held by a lecturer is considered as a separate obstacle in coordinating internally PR and coordination with other parts. According to informant job informants are responsive and need high coordination speed.

\section{CONCLUSION}

Answering the purpose of this study then concludes research on roles and position Public Relations as a Management Function in Higher Education is:

1. The role of Public Relations at Private University tends to act as Communication technician and little role as Communication facilitator. This matter due to the organization and working arrangements of private universities do not provide many opportunities to play a role.

2. The position of Public Relations at the State University is a marginal position with the proven still many levels of bureaucracy that must be passed in carrying out its functions.

3. Performance of Public Relations related to the role and position in this research is considered positive and in accordance with the portion of work.

\section{IMPLICATION OF STUDY RESULT}

Practically, this research provides an explanation that the role and position of $\mathrm{PR}$ in private universities can not play a role and gain a position good. The role and position of the PR is influenced by the rigid rules relating to organization and work procedures endorsed by the government. Limited resources are obstacles are quite heavy faced by PR. Humas run public 
relations activities not to the strategic level. Academically, the concept of PR excelence and the dominant coalition of Public Relations in an order organizations at state universities can not be realized optimally. Roles and positions the strategic is not obtained by PR. Public Relations should have a role up on level of expert presciber by conducting two way communication (twoway communications).

The ideal position is where the PR is in a central position, has a coalition which is dominant in organizational communication. Socially, this research can provide an explanation that the role problem and the strategic position of PR in an organization is ideal. Roles and positions ideal has implications PR can work optimally in performing functions communication as an organization.

\section{BIBLIOGRAPHY}

Ananto, Elizabeth Goenawan, 2004, Public Realationa As Dominant Coalition, Is it Possible?, in Ridwan Nyak Baik \& Irmulan Sati T (eds), Dominant Coalition, Critical Reflections on the Role of Public Relations in Management, Jakarta, BPP PERHUMAS.

Bogdan and Taylor, 1975, in J. Moleong, Lexy (1989), Qualitative Research Methodology, Bandung, Remadja Karya.

Cutlip, Scott M., et al., 1985, Effective Public Relations, Fifth Edition, New Jersey, Prentice Hall International Inc.

Gozali, Dodi M, 2010, Communication Measurement: Concepts and Applications of Public Relations Performance Measurement, KITA.com Books.

Grunig, James E., and Todd Hunt, 1984, Managing Public Relations, New York, Holt, Rinehart and Winston.

Khasali, Rhenald, 2010, Public Relations Management: Concepts and Applications in Indonesia, Graffiti Publisher.

Moleong, 2004, Qualitative Research Methods, Bandung, Youth Rosda Karya. 